\title{
POLITIK DINASTI PADA KANDIDASI PEREMPUAN DALAM PILKADA SERENTAK 2015 DI JAWA TENGAH
}

\author{
Fitriyah \\ Departemen Politik dan Pemerintahan, Fakultas Ilmu Sosial dan Ilmu Politik, \\ Universitas Diponegoro \\ E-mail: fitriyasemarang@yahoo.co.id
}

\begin{abstract}
The Fact that candidacy of women in simultaneously local head election (pilkada serentak) 2015 at Central Java more give opportunities for the wife or daughter of the head/former head of region, indicating women's candidacy opportunities are limited to elites (political dynasty) and therefore exclusive, is contradict with norm of democracy which is inclusive. The studies aim to analyze practice of political dynasty in women candidacy in concurrently local election 2015 at Central Java, previous studies are see it as negative for democracy. This Study also to make recommendation on this pattern of nomination. This study uses literature study. The data sources are literatures, documents and the news media that relevant, both published or no published. The Information that were collected then recorded, processed and analyzed. The study result shows that the nomination women as candidate based kinship no inevitable faced on internal and external barriers of women in politics. Strategy of political dynasty for women can be read as affirmation policy which are not provided by regulation pilkada. However, this study recommend a more inclusive (open) competition within pilkada through decline threshold limit candidation for party that nominee women as candidate in pilkada.
\end{abstract}

Keywords: political dynasty; woman candidacy; simultaneously local head election; Central Java; affirmation policy

\begin{abstract}
Abstrak
Pencalonan perempuan dalam pilkada serentak 2015 di Jawa Tengah yang lebih memberi ruang bagi para istri atau putri dari kepala daerah/mantan kepala daerah mengindikasikan peluang pencalonan perempuan terbatas pada keluarga elit politik (politik dinasti). Hal ini bisa disebut eksklusif sebagai bertentangan dengan hakekat demokrasi yang sifatnya inklusif. Terkait fakta tersebut penelitian artikel ini bertujuan menganalisis praktik politik dinasti dalam pencalonan perempuan dan memunculkan rekomendasi atas pola pencalonan tersebut pada pilkada serentak 2015 di Jawa Tengah. Metode dalam penulisan artikel ini menggunakan analisis kepustakaan yang bersumber dari data literatur, dokumen serta pemberitaan media yang mendukung (relevan), baik yang dipublikasikan maupun tidak dipublikasikan. Informasi yang berhasil dihimpun kemudian dicatat, diolah dan dianalisis sehingga dapat ditemukan benang merah untuk selanjutnya dirangkai dalam satu karya ilmiah. Hasil kesimpulan artikel ini menunjukkan jika penominasian perempuan sebagai kandidat berbasis kekerabatan tidak terelakkan jika dihadapkan pada hambatan internal dan eksternal perempuan dalam politik. Jika studi-studi sebelumnya melihat politik dinasti sebagai hal negatif, studi ini menunjukkan politik dinasti bagi perempuan bisa dibaca sebagai bentuk afirmasi yang tidak disediakan oleh regulasi pilkada. Namun demikian, artikel penelitian ini menyarankan sebuah kompetisi yang lebih inklusif (terbuka) dalam pilkada yaitu dengan intervensi regulasi melalui penurunan ambang batas pencalonan bagi partai politik yang mengusung perempuan sebagai calon dalam pilkada.
\end{abstract}

Kata kunci: politik dinasti; pencalonan perempuan; pilkada serentak; Jawa Tengah; kebijakan afirmasi 


\section{Jurnal Ilmu Sosial Vol. 17 | No. 1 | Edisi Januari - Juni 2018 |Hal. 39-52}

\section{PENDAHULUAN}

Pilkada Serentak 2015 di Jawa Tengah yang diikuti oleh 21 kabupaten/kota telah mencatat prestasi dengan terlibatnya tujuh perempuan calon kepala daerah dan 8 (delapan) perempuan calon wakil kepala daerah. Sebelumnya, partisipasi perempuan dalam pilkada lebih banyak terjadi di provinsi Jawa Timur dan Sulawesi Utara (Anggarini, 2011: 46). Pilkada serentak 2015 di Jawa Tengah memang sudah menyertakan perempuan sebagai calon dalam jumlah yang signifikan, namun rekrutmen perempuan dalam pilkada di Jawa Tengah cenderung masih mengusung perempuan yang punya hubungan keluarga dengan petahana dan mantan kepala daerah atau politik dinasti. Pola ini tidak ditemukan untuk lakilaki yang dicalonkan dalam pilkada di Jawa Tengah. Pola dinasti pada pencalonan perempuan ini nyaris sama seperti cara rekrutmen di pemilu legislatif. Penelitian sebelumnya dalam pemilu legislatif 2014, dalam jumlah yang cukup, sejumlah calon legislatif di DPRD Jawa Tengah bersifat politik dinasti. Mereka masih memiliki hubungan keluarga dengan elit partainya (Fitriyah dan Supratiwi, 2015). Hal yang sama juga ditemukan pada penelitian Pusat Kajian Politik (Puskapol) UI 2014 pada calon anggota DPR.

Dalam sistem politik demokrasi disepakati cara mengisi jabatan-jabatan politik melalui suatu pemilu yang periodik, terbuka, bebas dan adil. Schumpeter (2013: 411) memaknai demokrasi sebagai sistem untuk membuat keputusan-keputusan politik, dimana individu-individu memperoleh kekuasaan memutuskan melalui sebuah pertarungan yang kompetitif dalam memperebutkan suara rakyat. Definisi ini tidak lepas dari esensi demokrasi, adalah sebuah pemerintahan oleh rakyat dan karenanya partisipasi politik rakyat adalah suatu keniscayaan. Kebijakan pelibatan rakyat juga sebagai esensi dari politik otonomi daerah dan desentralisasi. Berdasarkan pada penjelasan ini, maka melalui pilkada langsung rakyat di daerah punya akses untuk menentukan siapa yang lebih patut memerintah sekaligus berkesempatan menilai keberhasilan dan kegagalan penguasa yang memerintah tersebut. Dalam skala nasional, kebijakan pelibatan rakyat langsung di Indonesia sudah dimulai sejak Pilpres 2004, sedangkan pilkada (langsung) adalah turunan dari pilpres (langsung) yang dilaksanakan di tingkat lokal.

Dalam politik demokrasi juga berlaku hukum kesamaan derajat antar semua jenis kelamin, artinya semua warga negara baik laki-laki maupun perempuan terbuka kesempatan yang sama untuk berpartisipasi dalam pemilu, yang bermakna ada pengakuan hak memilih dan dipilih yang setara (Sharma, 2014). Sejak pemilu pertama di Indonesia (tahun 1955) perempuan Indonesia sudah punya hak pilih (right to vote). Namun sampai sekarang hak pilih perempuan tersebut belum menghasilkan keterwakilan yang seimbang dalam lembaga 


\section{Jurnal Ilmu Sosial Vol. $17 \mid$ No. $1 \mid$ Edisi Januari - Juni $2018 \mid$ Hal.39-52}

legislatif maupun untuk jabatan-jabatan eksekutif yang diisi melalui pemilu. Sejak pemilu 2004, guna mencapai kesetaraan keterwakilan perempuan (representatif), pemerintah telah menerbitkan kebijakan aksi afirmasi melalui sistem kuota 30\% bagi lembaga-lembaga strategis, terutama lembaga legislatif dan partai politik (Kartikasari, 2013). Kebijakan afirmasi kuota ini makin dikuatkan sejak pemilu 2009 melalui kebijakan sistem selangseling (zipper system) dalam penyusunan daftar calon (Bessel, 2010). Namun berbeda dalam pilkada tidak ada kebijakan afirmasi (Astriyo, 2010) padahal perempuan punya hambatan kultural dan struktural dalam politik, Svedova (2005: 33-34) mengkategorikannya atas hambatan politik, sosio-ekonomi, dan psikologis atau sosio-kultural.

Begitupun program aksi afirmasi berupa sistem kuota 30\% dan sistem zipper untuk menominasikan perempuan di pemilu legislatif nyatanya belum mampu mendorong perempuan masuk ke parlemen secara mudah. Kebijakan legal-quota ini masih membutuhkan sejumlah prasyarat, seperti sistem pemilu proporsional tertutup yang lebih ramah kepada perempuan dan mengadopsi voluntary party-quota. Temuan Bessel (2010) dari 15 negara demokrasi yang jumlah perempuan di lembaga legislatif mencapai 30\%, sebanyak 13 negara memakai sistem proporsional. Jika sejak Pemilu 1955 Indonesia menggunakan sistem proporsional, namun jumlah perempuan yang menjadi anggota DPR tetap kecil, Bessel (2010) melihatnya sebagai persoalan komitmen partai.

Sementara itu riil politiknya, bahwa faktor kedekatan perempuan calon legislatif (caleg) dengan elit parpol dan elit penguasa masih signifikan dalam pencalonan dan keterpilihan di DPR dan DPRD (Fitriyah dan Supratiwi, 2015), menunjukan program aksi afirmasi dalam pemilu legislatif belum sukses mempercepat capaian kesetaraan proporsi lebih seimbang antara perempuan dan laki-laki di parlemen, juga belum memberi jaminan kesempatan yang sama di antara para perempuan itu sendiri. Partai politik juga belum mengembangkan sistim kaderisasi yang kuat untuk meningkatkan keterwakilan perempuan dalam pencalonan, padahal peran partai politik sangat strategis dalam pencalonan (Wulandari dan Agustyati (dkk), 2014:64; Rahayu, 2014:30-32).

Bagi perempuan, agar terpilih sebagai anggota parlemen memiliki tiga hambatan penting dalam proses seleksi pencalonan yang dilakukan oleh partai sebagai kandidat dan akan diseleksi oleh pemilih saat pemilu (Matland, 2005: 93). Pada semua tahapan ini perempuan menjumpai hambatan, jika tahap pertama adalah hambatan internal, maka hambatan kedua dan ketiga adalah hambatan eksternal. Terdapatnya hambatan perempuan untuk terjun di politik bisa dibaca dari siapa saja perempuan yang terjun dan memperoleh jabatan politik. Widaryanto dan Pramono (Djojosoekarto dan Sandjaja 2008: 189-190) mengklasifikasikannya dalam tiga kelompok, yakni: (1) memperoleh jabatan politik karena 


\section{Jurnal Ilmu Sosial Vol. $17 \mid$ No. $1 \mid$ Edisi Januari - Juni 2018 | Hal.39-52}

memiliki hubungan tertentu dengan laki-laki (pejabat legislatif/eksekutif) sebagai istri atau anak; (2) sudah terbebas dari tugas membesarkan anak-anaknya; dan (3) kelompok usia muda, umumnya para aktivis (ormas, LSM atau organisasi ektra kampus). Studi ini mengindikasikan faktor relasi dengan elit laki-laki memberi probabalitas lebih kuat bagi perempuan masuk dan terjun ke dunia politik pilkada.

Menguatnya politik kekerabatan dan dinasti sejauh ini oleh banyak pihak dinilai

pihak kemunduran dari demokrasi. Atas dasar argumentasi tersebut semestinya hak untuk dipilih bersifat terbuka atau inklusif. Djati (2013) memaknai dinasti politik atau politik dinasti sebagai strategi politik untuk tetap mengawal keberlangsungan kekuasaan dengan cara mewariskannya kepada orang lain yang masih menjadi sanak keluarga. Dinasti politik dalam praktiknya menghalangi kesempatan yang luas bagi masyarakat untuk terlibat dalam suksesi kekuasaan. Terkait dengan kesempatan perempuan secara jumlah, ada peningkatan perempuan menjadi calon dalam pilkada.

Artikel ini ditulis untuk menganalisis praktik politik dinasti dalam pencalonan perempuan pada pilkada serentak 2015 di Jawa Tengah untuk menjawab rumusan masalah apakah pencalonan perempuan sebagai sebuah kebaikan ataukah hal sebaliknya. Artikel ini bertujuan memunculkan rekomendasi atas pola tersebut. Penelitian mengenai pencalonan perempuan dalam kontestasi politik pada kajian sebelumnya lebih melihat politik dinasti sebagai hal negatif (Djati, 2013), sedangkan dalam penelitian Susanti (2017) menyimpulkan pencalonan perempuan sebagai suatu ancaman bagi demokrasi. Studi-studi sebelumnya juga tidak spesifik menghubungkan politik dinasti dengan pencalonan perempuan dalam pilkada, namun lebih menekankan pada pemilu legislatif. Selain itu, fenomena politik dinasti yang paling sering diangkat adalah kasus di provinsi Banten dan provinsi Sulawesi Selatan, bukan provinsi Jawa Tengah.

\section{METODE PENELITIAN}

Fokus kajian artikel ini adalah pada pencalonan perempuan dalam pilkada serentak 2015 di Jawa Tengah. Kajian ini menggunakan analisis kepustakaan. Menurut Zed (2004: 1 -2) dalam studi kepustakaan, peneliti melakukan penelusuran pustaka sekaligus memanfaatkan sumber perpustakaan untuk memperoleh data. Sumber data kajian ini didapat dari literatur, dokumen serta pemberitaan media yang mendukung (relevan), baik yang dipublikasikan maupun tidak dipublikasikan. Informasi yang berhasil dihimpun kemudian dicatat, diolah dan dianalisis keterkaitannya sehingga dapat ditemukan benang merahnya untuk selanjutnya dirangkai dalam satu karya ilmiah. 


\section{Jurnal Ilmu Sosial Vol. 17 | No. 1 | Edisi Januari - Juni 2018 | Hal.39-52}

\section{HASIL DAN PEMBAHASAN}

Pilkada serentak tahun 2015 adalah kali pertama pilkada yang diselenggarakan secara bersamaan di beberapa daerah di Indonesia. Mengacu kepada UU No. 8 tahun 2015, pelaksanaan pilkada serentak dilakukan dalam tiga gelombang. Komisi Pemilihan Umum (KPU) menetapkan tanggal 9 Desember 2015 sebagai waktu pilkada serentak gelombang pertama bagi kepala daerah yang memiliki Akhir Masa Jabatan (AMJ) berakhir pada tahun 2015. Selanjutnya pilkada serentak gelombang kedua diselenggarakan pada 15 Februari 2017 bagi kepala daerah yang memiliki AMJ 2016 dan 2017, dan gelombang ketiga pada 27 Juni 2018 bagi kepala daerah yang memiliki AMJ 2018 dan 2019. Adapun pilkada serentak total seluruh Indonesia akan digelar pada tahun 2024.

Pilkada serentak tahun 2015 diikuti oleh sebanyak 269 daerah, yang tersebar pada 9 pilkada provinsi, 36 pilkada kota, dan 224 pilkada kabupaten. Dari 269 daerah tersebut ada lima daerah yang pada akhirnya ditunda penyelenggaraannya sebagai akibat (dispute) persoalan pencalonan, yaitu provinsi Kalimantan Tengah, kabupaten Simalungun, kota Pemantang Siantar, kota Manado, dan kota Fak-Fak. Namun demikian secara umum pilkada serentak 2015 dinilai berlangsung sukses.

Jawa Tengah menyertakan sejumlah pilkada terbesar kedua setelah Sumatera Utara dalam pilkada serentak 2015, ada sebanyak 21 kabupaten/kota atau $60 \%$ dari total 35 kabupaten/kotanya. Secara umum pilkada serentak di Jawa Tengah juga berjalan lancar, meski dalam laporan Bawaslu Jateng ditemukan 488 pelanggaran yang pada umumnya bentuk pelanggaran pengulangan (repetisi) pada pemilu-pemilu sebelumnya.

Dari 269 daerah yang menyelenggarakan pilkada memiliki jumlah 1.614 calon kepala daerah dan wakil kepala daerah. Dari 1.654 calon yang mengajukan diri terdapat 212 calon $(12,81 \%)$ pernah menduduki jabatan, baik sebagai mantan maupun petahana kepala daerah dan wakil kepala daerah. Sebanyak tujuh orang di antaranya adalah perempuan berstatus petahana bupati dan enam orang perempuan adalah petahana wakil bupati (infopilkada.kpu.go.id). Ini berarti pilkada serentak 2015 lebih diramaikan oleh calon pendatang baru. Dari total calon yang mencapai 1.614 calon tersebut terdapat 122 perempuan (7,37\%). Hampir semua perempuan berpartisipasi sebagai calon di pilkada kota/kabupaten dan hanya satu di pilkada provinsi yakni sebagai calon Gubernur Sulawesi Utara. Dari 122 calon perempuan, sebanyak 55 (45\%) orang dicalonkan sebagai kepala daerah dan 67 (55\%) orang sebagai calon wakil kepala daerah (infopilkada.kpu.go.id). Dilihat dari profil para calon tersebut, sebesar 38,06\% calon kepala daerah dan sebesar $12,12 \%$ calon wakil kepala daerah mewakili politik dinasti (Paat, 2015). Data tersebut setidaknya menunjukkan kuatnya jaringan kekerabatan sebagai pintu masuk keterlibatan perempuan dalam pilkada. 


\section{Jurnal Ilmu Sosial Vol. 17 | No. 1 | Edisi Januari - Juni 2018 | Hal.39-52}

Merujuk pada data jumlah perempuan sebagai calon dalam pilkada serentak 2015, banyaknya prosentase perempuan yang dicalonkan sebesar 7,32\% menunjukkan keterlibatan perempuan dalam pilkada masih rendah. Pengalaman pilkada sebelumnya juga sama. Dari dokumentasi JPPR menunjukkan bahwa dari 466 pilkada kabupaten/kota dan 33 provinsi tahun 2005-2008 yang diikuti 3.652 calon, hanya ada 134 (3,66\%) perempuan yang menjadi calon (Satriyo, 2010: 245). Posisi perempuan dalam pencalonan juga lebih didominasi sebagai calon wakil kepala daerah ketimbang sebagai calon kepala daerah. Data LSI (2007: 2) menunjukkan pilkada pada tahun 2005 hingga Desember 2006 sebanyak $72,5 \%$ perempuan diantaranya ditempatkan pada posisi wakil dan hanya $27,5 \%$ yang menjadi kepala daerah.

Fakta ini memperlihatkan bahwa dominasi laki-laki masih sangat kuat di dalam proses pencalonan pilkada. Sempitnya ruang perempuan dalam pencalonan pilkada serasa makin lengkap dengan fakta bahwa yang dicalonkan kebanyakan adalah para istri (ikatan perkawinan) dan anak(hubungan darah) dengan kepala daerah, petahana maupun mantan kepala daerah. Pola ini yang juga ditemukan di kabupaten/kota di Jawa Tengah dalam pilkada serentak 2015. Kecenderungan politik kekerabatan atau dinasti dalam pencalonan ini mengulang pola dari pilkada sebelumnya, seperti munculnya para istri petahana sebagai calon kepala daerah, yakni Widya Kandi Susanti di pilkada Kendal 2010, Titik Suprapti di pilkada Sukoharjo 2010, Susi Iriyani di pilkada Batang 2011, dan putri petahana Kusdinar Yuni Untung Sukowati di pilkada Sragen 2010. Kecenderungan ini juga ada pada pola pencalonan dalam pemilu DPRD Jawa Tengah tahun 2014 (Fitriyah dan Supratiwi, 2015).

Berdasarkan ukuran inklusif dan eksklusif dalam rekruitmen politik, bisa ditarik kesimpulan bahwa praktik yang ditemukan dalam pencalonan pilkada lebih memenuhi ukuran eksklusif dengan bukti masih kuatnya politik dinasti. Politik dinasti diyakini tidak memberi ruang kompetisi yang sehat bagi semua calon yang memiliki keinginan untuk maju dan berkompetisi dalam pilkada. Melalui kedekatan dengan petahana, maka calon yang sedinasti dengan petahana punya akses pada sumber daya negara yang melekat pada diri petahana. Posisi calon yang sedinasti sama besarnya dengan posisi petahana andaikata ia kembali bersaing dalam pilkada. Pada pilkada serentak 2015 masih bertahannya politik dinasti dalam pencalonan dipicu oleh Keputusan Mahkamah Konstitusi. Aturan yang semula melarang keluarga petahana ikut kompetisi pilkada sudah tidak ada lagi. Lewat putusan perkara nomor 33/PUU- XIII/2015, MK menganulir Pasal 7 huruf (r) UU Nomor 8 tahun 2015 terkait larangan mencalonkan diri bagi seseorang yang memiliki konflik kepentingan dengan petahana.

Fenomena politik dinasti dalam pilkada serentak di Jawa Tengah bisa dicermati dari 


\section{Jurnal Ilmu Sosial Vol. $17 \mid$ No. 1 | Edisi Januari - Juni 2018 | Hal.39-52}

perempuan petahana kepala daerah maupun mantan kepala daerah sebagai calon. Dari total 104 orang calon kepala daerah maupun wakil kepala daerah di 21 kabupaten/kota, terdapat 15 perempuan atau 26,31\%. Mereka ini berkompetisi di 11 daerah. Dari 15 orang calon, sebanyak 7 orang $(46,66 \%)$ maju sebagai calon kepala daerah, 8 orang $(53,33 \%)$ sebagai calon wakil kepala daerah. Hasil pilkada menunjukkan 9 orang $(60 \%)$ calon perempuan terpilih.

Seperti yang sudah dijelaskan pada bagian sebelumnya, sejumlah fakta menarik ditemukan dari pencalonan perempuan dalam pilkada serentak di Jawa Tengah, yang paling fenomenal adalah pasangan calon yang keduanya adalah perempuan. Pasangan ini berlaga di kabupaten Klaten, yaitu Sri Hartini sebagai calon bupati dan Sri Mulyani sebagai calon wakil bupati dan mereka menang terpilih. Berikutnya, pilkada Kendal diikuti dua pasangan calon yang kedua calon bupati adalah perempuan, sedangkan pilkada kabupaten Pekalongan juga diikuti dua pasangan calon yang kedua calon wakil bupati adalah perempuan. Fakta lain yang patut diapresiasi dari 11 daerah yang terdapat perempuan sebagai calon, hanya dua daerah yang calon perempuannya gagal terpilih, yaitu Wonosobo dan kota Pekalongan.

Mereka yang terpilih terdiri atas empat calon bupati, yakni Sri Sumarni (Grobogan), Mirna Annisa (Kendal), Kusdinar Untung Yuni Sukowati (Sragen), Sri Hartini (Klaten), dan enam calon wakil bupati/walikota terpilih adalah Diah Hayuning Pratiwi (Purbalingga), Yuli Hastuti (Purworejo), Sri Mulyani (Klaten), Arini Harimurti (Pekalongan), Windiarti Agustina (kota Magelang), Hevearita Gunaryati Rahayu (kota Semarang). Data ini menunjukkan elektabilitas perempuan cukup tinggi, terbukti ketika dicalonkan mereka terpilih. PDIP adalah partai pengusung pasangan calon yang menyertakan perempuan terbanyak, yakni delapan pasangan calon yang diusung secara koalisi dan satu pasangan calon tanpa koalisi. Peringkat berikutnya Gerindra yang mengusung enam pasangan calon dengan membentuk koalisi partai-partai.

Penelusuran atas latar belakang dari para calon perempuan di Indonesia menunjukkan sebagian besar mereka punya hubungan kekerabatan atau dari dinasti petahana kepala daerah maupun mantan kepala daerah yang bisa dilihat pada tabel 1. Basis kekerabatan dengan elit politik dalam rekruitmen perempuan sebagai calon dalam pilkada sudah ada dalam pemilu legislatif. Dari Daftar Calon Tetap (DCT) DPR pemilu 2014 juga terlihat jika partai belum optimal melakukan kaderisasi perempuan yang disiapkan memasuki parlemen. Hal ini tampak dari fakta lapangan, bahwa mayoritas perempuan yang dicalonkan, sebanyak 1.718 (69,7\%) bukan kader partai, hanya 747 (30,3\% ) caleg kader partai (Formappi, 2013). Politik dinasti juga sangat kuat terasa dalam pencalonan perempuan dalam pilkada serentak 2015 di Jawa Tengah. 
Jurnal Ilmu Sosial Vol. 17 | No. 1 | Edisi Januari - Juni 2018 | Hal.39-52

Tabel 1. Politik Dinasti Pencalonan Perempuan Pada Pilkada Serentak 2015 di Jawa Tengah

\begin{tabular}{clcc}
\hline No. & \multicolumn{1}{c}{ Profil Calon } & $\begin{array}{c}\text { Calon } \\
\text { Kepala } \\
\text { Daerah }\end{array}$ & $\begin{array}{c}\text { CalonWakil } \\
\text { Kepala- } \\
\text { Daerah }\end{array}$ \\
\hline 1. & Jaringan kerabat dengan petahana/mantan & - & 3 \\
\hline 2. & $\begin{array}{l}\text { Jaringan kerabat dengan petahana/mantan, sta- } \\
\text { tus sebagai petahana bupati/wakil bupati }\end{array}$ & 2 & - \\
\hline 3. & $\begin{array}{l}\text { Jaringan kerabat dengan petahana/mantan, sta- } \\
\text { tus sebagai anggota/mantan anggota DPRD }\end{array}$ & 1 & 1 \\
\hline 4. & Status sebagai petahana wakil bupati & 1 & - \\
\hline 5. & Status sebagai anggota/mantan anggota DPRD & 1 & 2 \\
\hline 6. & Status sebagai politisi & 1 & - \\
\hline 7. & Bukan politisi & 1 & 2 \\
\hline & Jumlah & 7 & 8 \\
\hline
\end{tabular}

Sumber: diolah dari kpu.go.id dan pemberitaan (online)

Gambaran jelas tentang politik dinasti dalam pilkada kabupaten/kota di Jawa Tengah didapat dari pilkada Klaten. Sebagaimana telah diulas di atas, pilkada Klaten 2015 dimenangkan oleh pasangan Sri Hartini dan Sri Mulyani yang diusung oleh PDIP, Nasdem, PPP, PKS. Keduanya sama-sama istri bupati Klaten, Sri Hartini (54 tahun) adalah petahana wakil bupati. Ia istri dari mantan bupati Klaten periode 2000-2005 Haryanto Wibowo (almarhum). Kiprahnya di dunia politik berawal ketika sang suami, yang saat itu menjabat Ketua DPC PDIP Klaten meninggal. Sri Hartini lalu menggantikan suaminya sebagai Ketua DPC PDIP (2006-2010) dan sebagai bendahara DPD PDIP Jateng (20102015). Sedangkan pasangannya sebagai calon wakil bupati Sri Mulyani (38 tahun) adalah istri petahana bupati Sunarno. Pasangan calon ini terpilih dengan perolehan 321.593 suara $(48,90 \%)$. Kemenangan mereka tak lepas dari peran petahana bupati yang merupakan ketua DPC PDIP dan ketua tim pemenangan (Sunantri dan Verdana, 2015)

Pola Klaten ini menunjukkan jalur cepat perempuan dalam pencalonan pilkada melalui jaringan kekerabatan atau politik dinasti. Karier politik dari keduanya tidak dipungkiri karena akses yang didapat berkat politik dinasti. Karier politik Diah Hayuning Pratiwi (Purbalingga), Yuli Hastuti (Purworejo), Kusdinar Untung Yuni Sukowati (Sragen), Widya Kendi Susanti (Kendal) adalah contoh lain dari akses perempuan yang membangun karier politik dan kemudian dicalonkan dalam pilkada berkat kedekatan famili dengan elit penguasa. 


\section{Jurnal Ilmu Sosial Vol. 17 | No. 1 | Edisi Januari - Juni 2018 | Hal.39-52}

Diah Hayuning Pratiwi atau Tiwi (28 tahun) adalah putri Triyono Budi Sasongko yang selama dua periode (2000-2010) sebagai bupati Purbalingga. Setelah masa jeda satu periode Purbalingga dipimpin orang lain, kini Tiwi “masuk" Purbalingga. Ia tak mengambil jalan langsung ke pemimpin puncak (bupati), melainkan melalui jalur wakil bupati mendampingi petahana wakil bupati $\mathrm{H}$. Tasdi, SH, MM.

Yuli Hastuti (51 tahun) adalah istri bupati Purworejo (2005-2008) Kelik Sumrahadi. Yuli memulai karier politiknya dengan bergabung di Partai Golkar, suaminya adalah ketua DPD Partai Golkar Purworejo.Yuli menjadi Ketua HWK Partai Golkar Purworejo (2000sekarang). Ia dicalonkan di pemilu 2009 dan terpilih, ia menjadi Ketua DPRD Purworejo (2009-2014). Pada pemilu 2014 Yuli kembali dicalonkan tetapi gagal terpilih. Ia kemudian maju pada pilkada 2015 sebagai calon wakil bupati mendampingi Agus Bastian SE., MM dan pasangan ini terpilih.

Kusdinar Untung Yuni Sukowati (41 tahun) adalah putri bupati Sragen dua periode (2001-2011) Untung Wiyono. Yuni mengawali karir politiknya pada tahun 2009 sebagai anggota dan Ketua DPRD Sragen dari PDIP. Tahun 2011 Yuni dicalonkan PDIP sebagai kepala daerah tetapi gagal terpilih. Pada pemilu 2014 Yuni kembali terpilih sebagai anggota DPRD Sragen. Pada pilkada 2015, Yuni berpasangan dengan Dedy Endriyatno, politisi PKS yang maju sebagai pasangan calon dan diusung oleh koalisi Gerindra dan PKS. Pada saat itu Yuni terpilih menang.

Widya Kandi Susanti adalah petahana bupati Kendal. Sebelumnya, adalah wakil ketua DPRD Kendal (2009-2010). Ia merupakan istri mantan bupati Kendal (2000-2010) Hendy Boedoro. Pada pilkada 2010, Widya yang disung oleh PDIP terpilih sebagai bupati Kendal. Namun, pada pilkada 2015 Widya yang diusung koalisi PDIP, Nasdem, PKB kalah oleh Mirna Anissa yang diusung koalisi Gerindra, PKS dan Hanura. Politik dinasti sangat kental pada diri Widya.

Politik dinasti dinilai tidak memberi ruang kompetisi yang sehat bagi semua calon yang berkompetisi dalam pilkada. Melalui kedekatan dengan petahana, maka calon yang masih satu dinasti dengan petahana memiliki akses pada sumber daya negara yang melekat pada petahana. Posisi calon tersebut sama kuatnya dengan posisi petahana yang kembali bersaing dalam pilkada. Menguatnya politik dinasti dipicu oleh Keputusan Mahkamah Konstitusi. UU pilkada No. 8 Tahun 2015 yang semula melarang keluarga petahana ikut kompetisi pilkada sudah tidak berlaku lagi. Lewat putusan perkara nomor 33/PUUXIII/2015, MK menganulir Pasal 7 huruf (r) UU Nomor 8 tahun 2015 terkait larangan mencalonkan diri bagi seseorang yang memiliki konflik kepentingan dengan petahana. Namun patut juga dicatat bahwa politik dinasti juga merupakan pilihan pragmatis partai 
Partai politik adalah jalur utama untuk berpartisipasi politik, dan merupakan institusi yang paling penting yang mempengaruhi tingkat partisipasi politik perempuan. Pada sebagian besar negara, partai politik bertanggung jawab untuk melakukan rekrutmen dan seleksi calon (Sherma, 2014, Budiardjo, 1981:14-17; Hofmeister and Grabow, 2011: 16). Secara eksplisit dalam pasal 6A ayat (2) Amandemen UUD 1945 diatur bahwa partai politik memegang peran utama mengusung pasangan calon presiden dan wakil presiden untuk dipilih secara langsung oleh rakyat. Juga ditentukan partai politik sebagai peserta pemilu anggota DPR dan anggota DPRD (Pasal 22E ayat 3). Pola yang sama berlaku untuk pilkada di UU No. 32 tahun 2004 sebelum direvisi melalui UU No. 12 tahun 2008, yakni sebagai satu-satunya institusi pengusung calon. Walaupun setelah dilakukan revisi dibuka jalan bagi perseorangan dalam pencalonan, namun partai politik masih memainkan peran yang penting (Satriyo, 2010: 247).

Peran penting partai politik dalam mengusung perempuan sebagai calon dalam pilkada bisa dijelaskan dari mekanisme rekruitmen politik oleh partai politik. Pamungkas (2011: 92) menyebutkan ada tiga tahapan rekruitmen politik: (1) tahap sertifikasi (certification stage), yaitu tahap pendefinisian kriteria kandidasi, meliputi aturan-aturan pemilihan, aturan-aturan partai, dan norma-norma sosial informal; (2) tahap penominasian (nomination stage), meliputi ketersediaan (supply) calon yang memenuhi syarat dan permintaan (demand) dari penyeleksi pada saat memutuskan siapa yang dinominasikan; dan (3) tahap pemilu (election stage), tahap yang menentukan siapa yang memenangkan pemilu. Komitmen partai politik atas pencalonan dan keterpilihan perempuan dalam pemilu ditentukan pada semua proses rekruitmen politik tersebut.

Berdasar dari uraian di atas, maka kesempatan luas perempuan berpartisipasi dalam pilkada diawali oleh komitmen partai politik terhadap keterwakilan perempuan. Sayangnya, sistem politik Indonesia belum terbiasa memperhatikan pentingnya peran perempuan dalam politik. Hal ini terwakili pada penyikapan partai politik pada pencalonan selama ini. Sebagai gambaran dari evaluasi pemilu 1999, saat kebijakan afirmasi untuk pemilu dan kepengurusan partai politik belum diberlakukan, tidak satupun partai yang mencantumkan ketentuan tentang hak dan kesempatan untuk perempuan dalam aturan dasarnya (AD/ART) (Djojosoekarto dan Sandjaja 2008: 190). Saat ini kepengurusan partai politik secara dominan tetap diisi oleh elit laki-laki, yang dalam rekruitmen para calon laki-laki elit partai punya posisi sebagai penentu (Satriyo, 2010: 247).

Dalam pemilu, partai politik juga berperan sebagai mesin politik untuk memenangkan calon yang dinominasikan (Pamungkas, 2011:92), namun di dalam praktik fungsi sebagai mesin politik tidak dijalankan. Setelah nama-nama perempuan masuk dalam 


\section{Jurnal Ilmu Sosial Vol. $17 \mid$ No. 1 | Edisi Januari - Juni 2018 | Hal.39-52}

pencalonan, partai politik membiarkan mereka bekerja sendiri (Wulandari dan Agustyati dkk., 2014: 65). Padahal untuk keterpilihan dalam pilkada, pasangan calon memiliki kemungkinan terpilih manakala memiliki tiga modal utama, yakni: (1) modal politik, berupa dukungan politik baik dari rakyat dan dari kekuatan-kekuatan politik; (2) modal sosial, melalui modal sosialnya para kandidat calon tidak hanya dikenal oleh masyarakat, tetapi juga diberi kepercayaan; dan (3) modal ekonomi, tidak hanya untuk kampanye, tetapi juga untuk membangun relasi calon dengan pemilih guna memobilisasi pemilih saat kampanye, juga untuk politik uang (Marijan, 2006: 85-95). Terkait pentingnya modal ekonomi, kemampuan kandidat dalam menyiapkan dana yang cukup besar menjadi faktor penting di balik pencalonan yang dilakukan oleh partai politik (Haris, 2005). Politik dinasti yang bermakna calon berasal dari garis keturunan petahana, menjadi pilihan yang rnenarik bagi partai politik untuk sumber daya rekruitmen politik. Mereka punya modal keunggulan elektoral, seperti popularitas, kekuatan finansial, serta kemampuan memobilisasi massa menggunakan pengaruh tokoh kekerabatan politik yang sedang menjabat (Harjanto, 2011: 139). Data keterpilihan perempuan caleg di DPR RI menunjukkan dominasi jaringan kekerabatan dengan elit kekuasaan dan elit partai sebagai basis rekruitmen caleg hingga mencapai 36\%. Pola ini juga ditemukan pada pemilu 2009 bahkan mencapai 42\%. (Puskapol UI, 2014).

\section{KESIMPULAN}

Selama lebih dari satu dekade partisipasi perempuan dalam pencalonan pilkada cukup rendah. Apabila dalam pemilu legislatif diberlakukan kebijakan aksi afirmasi dalam rangka mendorong meningkatnya partisipasi perempuan di parlemen, tetapi dalam pilkada kebijakan semacam ini tidak ada. Padahal dalam masyarakat patriarki, perempuan mempunyai hambatan yang sama untuk berpartisipasi dalam semua jenis pemilu. Faktor penghambat ini yang menyebabkan jaringan kekerabatan dengan elit partai dan pejabat publik (politik dinasti) menjadi faktor penting bagi perempuan untuk berpartisipasi dalam pemilu termasuk pilkada. Secara umum dalam pilkada pola rekruitmen perempuan sebagai calon berbasis kerabat terindikasi menguat di Jawa Tengah telah berkontribusi pada banyaknya jumlah calon dari kelompok perempuan.

Meski saat ini politik dinasti menjadi sebuah "strategi" meningkatkan keterwakilan perempuan dalam pencalonan pilkada, namun untuk menjamin kesetaraan perlu dicarikan jalan keluar agar tidak membatasi regenerasi kepemimpinan lokal hanya berputar pada lingkaran elit penguasa. Begitu pula akses penguasaan sumber daya daerah pada kelompok elit penguasa dibatasi melalui transparansi dalam tata kelola pemerintahan daerah dan penguatan pengawasan internal maupun eksternal guna membatasi keinginan membangun politik dinasti. 


\section{Jurnal Ilmu Sosial Vol. 17 | No. 1 | Edisi Januari - Juni 2018 | Hal.39-52}

Tidak dipungkiri peran regulasi dalam memutus sejumlah persoalan pilkada sampai hari ini masih menjadi pilihan yang efektif, karenanya perbaikan atas kelemahan pencalonan perempuan dalam pilkada yang masih bergantung dan terbatas di lingkaran elit politik dilakukan dengan perbaikan regulasi. Mengikuti rekomendasi Perludem (Anggarini 2011), maka upaya mendorong partai politik semakin banyak mengusung perempuan sebagai calon perlu ada kebijakan afirmasi dalam pilkada dengan menurunkan syarat ambang batas pilkada (pilkada thresholds) bagi partai politik yang mengusung perempuan sebagai pasangan calon maupun yang salah satu calonnya adalah perempuan. Pengurangan ambang batas juga perlu dilakukan untuk syarat dukungan bagi perempuan yang ingin mencalonkan diri melalui jalur perseorangan (independen).

\section{DAFTAR PUSTAKA}

Anggarini, Titi (2011). Menata Kembali Pengaturan Pemilukada. Jakarta: Perludem

"Berbekal Pengalaman Jadi Istri Bupati: Duet "Srikandi" Menang di Klaten" (2015). Diunduh 10/12/2025. http://berita.suaramerdeka.com/smcetak/

Bessel, Sharon. (2010). "Increasing The Proportion of Women in the National Parlianment: Opportunites, Barriers, and Chalengges". Dalam Edward Aspinall and Marcus Mietzner (ed). Problems of Democratisation in Indonesia: Elections, Institutions and Society. Singapore: ISEAS Publishing: p. 219-242

Budiardjo, Miriam (1981). Pengantar Ilmu Politik. Jakarta: Gramedia

Djati, Wasisto Raharjo (2013). "Revivaisme Kekuatan Familiisme dalam demokrasi: Dinasti Politik Aras Lokal”. Jurnal Sosiologi Masyarakat, Vol. 18, No. 2: hal. 203-231

Djojosoekarto, Agung dan Utama Sadjaja (ed.) (2008). Transformasi Demokratis Partai Politik di Indonesia, Jakarta: Kemitraan dan STI

Fitriyah and Supratiwi, (2015).“ The Electability of Women Candidates in The Election of Central Java DPRD in 2014, Jurnal Komunitas, Vol.7, No.1: p.157-165

Formappi (2015). Anatomi Caleg Terpilih Pemilu 2014. Diunduh 1/1/2015 http:// parlemenindonesia.org/

Haris, Syamsuddin (2006). "Kecenderungan Pencalonan dan Koalisi Partai dalam Pilkada Langsung 2005", dalam Sri Nuryanti (ed). Analisis Proses dan Hasil Pilkada Langsung 2005, Jakarta: P2P LIPI: hal. 47-68

Harjanto, Nico (2011). "Politik Kekerabatan dan Institusionalisasi Partai Politik di Indonesia," Analisis CSIS, Vol. 40, No. 2: hal. 138-159

infopilkada.kpu.go.id 


\section{Jurnal Ilmu Sosial Vol. 17 | No. 1 | Edisi Januari - Juni 2018 | Hal.39-52}

Kartikasari, Dian (2013) "Keterwakilan Perempuan, Ketidakadilan dan Kebijakan Keadilan ke depan”. Makalah . Konferensi INFID: Pembangunan Untuk Semua, Jakarta 26 27 November . Diunduh 10/1/2015. infid.org/pdfdo/1385712674.pdf

Kemitraan Indonesia (2014). Patriarchal Barriers to Women's Political Participation in South-East Asia: Lessons from the Philippines, Cambodia, Malaysia, Indonesia, and Timor-Leste on Patriarchy and the Rise of Women's Participation in State Politics. Jakarta: Kemitraan Bagi Pembaruan Tata Pemerintahan

Kholiq, Nur, (2015).“Mantan Bupati Purworejo Keluar Penjara. Diunduh 18/1/2015. http:// suaramerdeka.com/

Lingkaran Survei Indonesia (2007). "Perempuan dan Pilkada". Kajian Bulanan LSI. Edisi 1, Mei

Marijan, Kacung (2006). Demokratisasi di Daerah: Pelajaran dari Pilkada Secara Langsung, Surabaya: Pustaka Eureka [dan] PusDeHAM

Matland, R.E (2005). “Enhancing Women's Political Participation: Legislative Recruitmentand Electoral Systems" dalam Julie Ballington et Azza Karam (eds). Women in Parliament: Be-yond Numbers. Stockolm: IDEA: p.93-111

Pamungkas, Sigit (2011). Partai Politik: Teori dan Praktik di Indonesia, Yogyakarta: Institute for Democracy and Welfarism

Maharddhika (2015). Wajah Muram Perempuan Calon Kepala Daerah. Diunduh September 15, 2015. http//www.rumahpemilu.org

Matland, R.E (2005). "Enhancing Women's Political Participation: Legislative Recruitmentand Electoral Systems" dalam Julie Ballington et Azza Karam (eds). Women in Parliament: Be-yond Numbers. Stockolm: IDEA: p.93-111

Muntoha, Ali dan Merie (2015). "Demokrat Pilih Istri Salim Sebagai Calon Bupati Rembang". Diunduh 10/6/2015. http://www.koranmuria.com/

Paat, Yustinus (2015). Perludem: Perlu Peningkatan Kuantitas dan Kualitas Perempuan di Pilkada, 2015. Diunduh 26/1//2015. http://www.beritasatu.com/nasional/324717

Pamungkas, Sigit (2011). Partai Politik: Teori dan Praktik di Indonesia, Yogyakarta: Institute for Democracy and Welfarism

“PDIP Percaya Diri Calonkan Dua Perempuan di Pilkada Malang” (2015) . Diunduh 13/7/ 2015. http://nasional.news.viva.co.id/

"Pilih Pemimpin Tak Bercela: Pelaksanaan Pilkada di Lima Daerah Ditunda", Kompas, 9 Desember 2015. Hlm.1

Puskapol FISIP-UI (2014). Pernyataan Pers: Analisis Perolehan Suara dalam Pemilu 2014: Oligarki Politik Dibalik Keterpilihan Caleg Perempuan, 2014. Dunduh 17/12/2014. http://www.puskapol.ui.ac.id/ 


\section{Jurnal Ilmu Sosial Vol. 17 | No. 1 | Edisi Januari - Juni 2018 |Hal.39-52}

Rahayu, Ruth Indiah (2014). The Success and the Barriers to Women's Representation in Southeast Asia: Between State Policies, Political Parties and Women's Movement . Jakarta: Partnership for Governance Reform (Kemitraan)

Satriyo, Hana A (2010). "Pushing The Boundaries Women in Direct Local Election and Local Government", In Problems of Democratisation in Indonesia: Elections, Institutions and Society, edited by Edward Aspinall and Marcus Mietzner, Singapore: ISEAS, hal. 243-263

Sunantri, Merawati dan Aristya Kusuma Verdana (2015). Pasangan Fenomenal. Diunduh 27/12/2015. http://berita.suaramerdeka.com/smcetak/

Sharma, Anju (2014). "Realizing Gender Responsive Governance \& Gender Equality Representatives in Democratic Society : A Concrete situation of Women Empowerment \& Participation in Politics", International Journal of Informative \& Futuristic Research (IJIFR), Vol 2, Issue 1

Shvedova, Nadezhda (2005). Obstacles to Women's Participation in Parliament. dalam Julie Ballington et Azza Karam (eds). Women in Parliament: Be-yond Numbers. Stockolm: IDEA: p. 33-51

Susanti, Martien Herna (2017). "Dinasti Politik dalam Pilkada di Indonesia". Journal of Government and Civil Society, Vol. 1, No. 2: hal. 111-119.

Wilhelm Hofmeister and Karsten Grabow (2011). Political Parties: Functions and Organisation in Democratic Societies, Singapore: Konrad Adenauer Stiftung

WRI, (2010) "Lembar Fakta WRI: Wajah Muram Keterwakilan Perempuan Dalam Pilkada di Indonesia“, 2010 . Diunduh 22/2/ 2016. http://wri.or.id/files/Factsheet

Wulandari, Lia, dan Khoirunnisa Agustyati (dkk) (2014). Pencomotan Perempuan Untuk Daftar Calon: Rekrutmen Calon Anggota DPRD Kabupaten/Kota untuk Memenuhi Kuota 30\% Perempuan dalam Pemilu 2014. Jakarta: Perludem

Zed, Mestika (2004). Metode Penelitian Kepustakaan. Jakarta: Yayasan Obor 